\title{
Antifungal activity of Hedychium coronarium J. König essential oil against Fusarium oxysporum Schlecht and Thanatephorus cucumeris (A.B. Frank) Donk in vitro
}

\author{
Atividade antifúngica do óleo essencial de Hedychium coronarium J. König sobre \\ Fusarium oxysporum Schlecht e Thanatephorus cucumeris (A.B. Frank) Donk in vitro
}

\author{
Maurício Reginaldo Alves dos Santos ${ }^{* 1}$, Renato Abreu Lima ${ }^{2,3}$, Cléberson de Freitas Fernandes ${ }^{1}$, \\ Andrina Guimarães Silva Braga ${ }^{2,3}$, Valdir Alves Facundo ${ }^{2}$ \\ ${ }^{1}$ Embrapa Rondônia, Porto Velho, Brasil \\ ${ }^{2}$ Doutorandos em Biodiversidade e Biotecnologia da Amazônia Legal, BIONORTE, \\ ${ }^{3}$ Laboratório de Química em Produtos Naturais da Universidade Federal de Rondônia, Porto Velho, Brasil.
}

\begin{abstract}
Fusarium oxysporum Schlecht and Thanatephorus cucumeris (A.B. Frank) Donk are fungi which cause some diseases in important plant cultures in Brazil - like bananas and beans. Hedychium coronarium J. König is a native plant from Asia that currently occurs in Brazil, where it is used in folk medicine to treat infections in general. The objective of this work was to evaluate the effect of the $\mathrm{H}$. coronarium essential oil from leaves on the in vitro growth of F. oxysporum and T. cucumeris colonies. Discs of $5 \mathrm{~mm}$ diameter from isolated cultures of each fungi were placed in the center of $90 \mathrm{~mm}$ diameter Petri dishes with potato dextrose agar. In the peripheral area of the dishes four discs of filter paper were placed with $10 \mu L$ of essential oil, extracted through distillation system. For a control treatment, discs without essential oil were used. A completely randomized design was used with four replications (of four dishes). Every 24 hours for 8 days the fungi growth was evaluated by measuring the diameter of the colonies. After 192 hours F. oxysporum colonies had $37.4 \mathrm{~mm}$ diameter in the treatment with essential oil, while in the control the diameter was $66.4 \mathrm{~mm}$. T. cucumeris colonies reached $11.9 \mathrm{~mm}$ diameter with essential oil and covered the dishes in the control. The results showed that the essential oil from leaves of $\mathrm{H}$. coronarium has an inhibitory effect on the in vitro growth of $\mathrm{F}$. oxysporum and $\mathrm{T}$. cucumeris, thus suggesting its potential use in agriculture, mainly with respect to banana and bean cultures.
\end{abstract}

Keywords: phytopathology, medicinal plants, biological control.

\section{Resumo}

Fusarium oxysporum Schlecht e Thanatephorus cucumeris (A.B. Frank) Donk são fungos causadores de doenças em grandes culturas de Rondônia, tais como banana e feijão. Hedychium coronarium J. König é uma planta nativa da Ásia e de grande distribuição no Brasil, onde é utilizada na medicina popular no tratamento de infecções em geral. O objetivo deste trabalho foi avaliar o efeito do óleo essencial de folhas de $\mathrm{H}$. coronarium sobre o crescimento in vitro de T. cucumeris $e \mathrm{~F}$. oxysporum. Para isto, discos de $5 \mathrm{~mm}$ de diâmetro de culturas de isolados de cada fungo foram colocados no centro de placas de Petri de $90 \mathrm{~mm}$ de diâmetro, contendo meio batata dextrose ágar (BDA), sendo que, na área periférica das placas, foram dispostos simetricamente quatro discos de papel-filtro cada um com $10 \mu \mathrm{L}$ de óleo essencial, extraído por meio de um sistema de arraste a vapor. Como controle, foram utilizados discos sem o óleo essencial. O delineamento foi inteiramente casualizado, com quatro repetições de quatro placas. Após 192 horas de cultivo, foram observadas colônias de F. oxysporum com diâmetro médio de 37,4 mm no tratamento com óleo essencial, enquanto que, no controle, o diâmetro médio das colônias foi de 66,4 mm. As colônias de T. cucumeris atingiram 11,9 mm de diâmetro no tratamento com óleo essencial, e cobriram toda a placa no controle. Os resultados obtidos mostram que o óleo essencial de folhas de $\mathrm{H}$. coronarium apresenta ação inibitória sobre o crescimento de F. oxysporum e de T. cucumeris in vitro, o que sugere seu potencial para utilização na agricultura, principalmente nas culturas do feijão e da banana.

Palavras-chave: fitopatologia, plantas medicinais, controle biológico.

mauricio@cpafro.embrapa.br

Recebido: 12/03/2014 Aceito: 12/03/2014 


\section{Introduction}

F usarium oxysporum belongs to the Moniliales order and Tuberculariaceae family. This is a soil fungus, staying for long periods in the chlamydospores form. It is disseminated mostly through infected seeds and seedlings, carried by irrigation and rainfall water, agricultural workers and supplements. The disease, known as Fusarium wilt, begins with the yellowing of older leaves, which progresses quickly to the younger (Zambolim et al., 2000). In recent years, the occurrence and severity of this disease have increased due mainly to the few preventive methods of control. The losses on income have been little studied. It is known however that the damages caused are highly variable and may affect between just a small number of plants and up to $80 \%$ of the crop, because the Fusarium wilt starts in small areas and, after some years of cultivation, disseminates throughout the crop. The disease is characterized by chlorotic and necrotic lesions from older leaves, with subsequent wilting, premature defoliation and stunting. Its characteristic symptom is observed in transverse and longitudinal sections, represented by the darkening of the xylem vessels (Cavalcanti et al., 2002). Another important fungus of the agriculture is Thanatephorus cucumeris (A.B. Frank) Donk. It is a plant pathogen which belongs to the Deuteromycetes botanical class, Polyporales order and Corticiaceae family, and is the teleomorph of Fusarium oxysporum. It occurs mainly in the imperfect phase, causing a variety of symptoms, such as damping off, root and fruit rot and cankers, which cause the death of plants in agriculture in a wide range of hosts (Shiraishi et al., 2003). The disease is common in regions with high temperature and humidity, with frequent rainfall. This is of fundamental importance because the disease limits the cultivation of beans in the tropics (Sartorato \& Rava, 1994). Both F. oxysporum and T. cucumeris are very significant in Brazilian agriculture, attacking great cultures - like bananas and beans.

Plant-derived compounds have been presented as alternatives to vector control, not only as new insecticidal agents, but also because they are in general environmentally safer than the synthetic agents (Mukhopadhyay et al. 2010; Santos et al. 2010).

Plant products offer resources for the production of insecticides, repellents and fungicides because they contain substances with various chemical structures, some of which have developed to protect the plant against insects or other aggressors (Castro et al., 2005). Many studies proved the biological effect of isolated substances from plant essential oils against different fungi. These provide a variety of resources of natural fungicides, and a great number of compounds have been extracted from essential oils (Chao \& Young, 2000). Essential oils are composed of several small volatile molecules found in leaves, roots, fruits, seeds or even stems of some species. Brazil is a great producer of essential oils and their isolated compounds, widely used in cosmetics, pharmaceuticals, food, beverage and pesticide industries (Silva \& Oliveira, 2000).

Hedychium coronarium J. König belongs to the Zingiberaceae botanical family, the largest of the Zingiberales order, with 53 genera and up to 1,200 native species from the tropics, especially the south and southeast of Asia (Santos et al., 2005). This species currently occurs in India, China, Japan and Brazil, mainly in high humidity habitats, such as on the margins of rivers and lakes, forming dense populations. In Brazil, its roots are used in the treatment of general infections, especially throat inflammation. In China, where it is a native species, it is used for treating rheumatism and as a tonic, an aphrodisiac and an antipyretic (Lorenzi, 2008).

Considering the presence of several described substances and their related effects in the species H. coronarium and the need for alternatives to control fungi proliferation in agriculture, its essential oil was tested in this study regarding inhibition of the growth of T. cucumeris and $F$. oxysporum under in vitro conditions, providing evidence to support future applications under field conditions.

\section{Material and method}

Leaves of $H$. coronarium were collected in the Federal University of Rondonia, in Porto Velho. The essential oil was extracted by a distillation system, according to the methodology described by Craveiro et al. (1981). The oil yield was of $5 \mathrm{~mL} \mathrm{~kg}-1$ of leaves. Discs of $5 \mathrm{~mm}$ diameter from isolated cultures of each fungus were placed in the center of $90 \mathrm{~mm}$ diameter Petri dishes with potato dextrose agar. In the peripheral area of the dishes four discs of filter paper were placed with $10 \mu \mathrm{L}$ of essential oil. For control, discs without essential oil were used. The dishes were kept at $25^{\circ} \mathrm{C}$ for 8 days. A completely randomized design was used with four replications (of four dishes). Every 24 hours the growth of the fungi was evaluated by measuring the diameter of the colonies. Statistical analyses were performed by Tukey test, at a $5 \%$ probability level.

\section{Result and discussion}

After 192 hours the essential oil of $H$. coronarium demonstrated an intense inhibitory effect on the growth of the T. cucumeris colonies. The oil treatment showed an average diameter of $11.9 \mathrm{~mm}$, compared with the control where the colonies covered the entire area of the dishes ( $90.0 \mathrm{~mm}$ diameter). In the evaluation of the growth of the F. oxysporum colonies, the inhibitory effect of the essential oil was also observed. Colonies of 37.4 $\mathrm{mm}$ average diameter had grown in the oil treatment, whereas in the experimental control the diameter was of $66.4 \mathrm{~mm}$. These values differed significantly, which 
demonstrates the activity of the essential oil on the inhibition of F. oxysporum growth.

Moreira \& Facundo (2005) analyzed the fixed and volatile compounds of $\mathrm{H}$. coronarium roots. The compounds found in the oil were 1,8-cineol (eucalyptol) $(6.56 \%)$, camphor $(8.92 \%), \alpha$-myrcene $(4.57 \%)$, curzerenone $(64.18 \%),(-)$-caryophyllene oxide $(1.49 \%),(Z)-1,-$ 3-pentadiene (3.06\%) and 3,5-dimethylphenol (1.51\%). Giordani et al. (2004) proved the antifungal effect of 1,8-cineol and camphor against Candida albicans and other fungi of the genera Microsporum, Trichophyton and Epidermophyton.

Some works have described the biological effects of $\mathrm{H}$. coronarium. Taveira et al. (2005) described the isolation of three compounds that might support the traditional use of $H$. coronarium for the treatment of inflammatory processes. In a previous phytochemical study, Matsuda et al. (2002) isolated several structure-related labdane diterpenes from $H$. coronarium, some of them possessing cytotoxic and anti-inflammatory properties, with inhibitory effects on the increase in vascular permeability and nitric oxide production. Braga et al. (1999) mentioned a potential anti-asthmatic activity of the rhizomes of $H$. coronarium, whose dichloromethane extract produced $86 \%$ inhibition of 5-lipoxygenase, at a concentration of $19 \mu \mathrm{g} \mathrm{mL}-1$ (Braga et al., 1999).

The in vitro control of T. cucumeris was the subject of an experiment by Silva (2005), who studied essential oils of Carapa guianensis Aublet, Orbignya oleifera Burret, Bertholletia excelsa H.B.K., Cedrela fissilis S. \& Moc., Copaifera officinalis Duckei Huber, Azadirachta indica L., Aspidosperma polyneurom M. Arg. and Glycine hispida L. against this fungus in dilutions of 1:3 (25\%), 1:1 (50\%) and 3:1 (75\%). The only efficient oils in controlling the fungi growth were those from C. guianensis and C. officinalis.

Other species have been studied as alternatives to control the agricultural fungi proliferation, most of them with respect to plants reported as medicinal. Pereira et al. (2006), studied the essential oil of Rosmarinus officinalis L., Allium cepa L., Ocimum basilicun L.., Mentha piperita L. and Origanum vulgare L., at 500, 1,000, 1,500 and 2,000 mg mL-1 on Fusarium sp., Aspergillus ochraceus Wilhelm., Alternaria flaves Link and Alternaria niger Van. growth and found that the O. vulgare oil inhibited the growth of all the fungi in all the used concentrations, except for $A$. niger, which had the mycelial growth inhibited only by concentrations of $1,000 \mathrm{mg} \mathrm{mL}^{-1}$. Other oils had effect only at $1,500 \mathrm{mg} \mathrm{mL}^{-1}$ and higher. Krauze-Baranowska et al. (2002), evaluated essential oils from Pinus ponderosa, $P$. resinosa and P. strobus on three Fusarium species. The most relevant result was the inhibition effect caused by $P$. ponderosa oil, which entirely inhibited the growth of all the tested fungi at 2 and $5 \%$ of dilution. Silva et al. (2005) tested the extract of Pterodon emarginatus Vog. fruits on the mycelial growth of the fungi Alternaria brassicae, Fusarium oxysporum, Rhizoctonia solani and Ceratocystis fimbriata for six days, and reported its effectiveness, with inhibitory effects of $62 ; 70 ; 74$ and $82 \%$, respectively. The authors argue that this can be an ecologically and economically viable alternative, since the fruits are obtained without injury to the trees. Pereira et al. (2005) tested essential oils of Matriocaria chamomilla L., Rosmarinus officinalis L. and Mentha piperita L. medicinal plants for control of in vitro culture contaminants at 5 and $10 \%$ dilutions. The first two were efficient against Aspergillus sp. and Penicillium sp. at 5\% and M. piperita was efficient at $10 \%$ dilution.

Joy et al. (2007) evaluated essential oils from fresh and dry rhizomes of H. coronarium by GC-MS and observed 44 and 38 compounds that represent, respectively, 93.91 and $95.41 \%$ of the total oils. The compounds in higher concentrations in the fresh and dry rhizomes were respectively 1,8-cineole - 41.42 and $37.44 \%$, $\beta$-pinene - 10.39 and $17.4 \%$, and $\alpha$-terpineol -8.8 and $6.7 \%$. Additionally, the authors evaluated the inhibitory effect of these essential oils against fungi and bacteria growth using the diffusion disc method and observed more efficiency of the oil from dry rhizomes than the oil from fresh rhizomes. Both samples showed more activity against Trichoderma sp. and Candida albicans than against Bacillus subtilis and Pseudomonas aeruginosa.

Martins et al. (2010) performed a leaf phytochemical analysis of $H$. coronarium and observed the presence of saponins (formation of persistent and abundant foam) and the absence of tannins, anthraquinones, alkaloids, and flavonoids. Using a thin-layer chromatography the authors also identified the presence of caryophyllene and myrcene in the crude essential oil obtained from $\mathrm{H}$. coronarium leaves, compounds that are known to have antimicrobial activity.

The great potential of natural aromatic substances have been described as an interesting alternative to control the proliferation of phytopathogens instead of synthetic substances, which have led to microorganism resistance and more significantly, environmental pollution, posing potential risk to animal and human health (Obongoya et al., 2009; Daferera et al., 2003; Fiori et al., 2000; Krauze-Baranowska et al., 2002; Almeida \& Regitano-D'arce, 2000; Farooq et al., 2002).

\section{Conclusion}

The results reported here show the in vitro efficiency of the essential oil of $H$. coronarium leaves against $F$. oxysporum and T.cucumeris, which suggests the potential of its use in agriculture, mainly with respect to banana and bean cultures. However, field experimentations and toxicological tests must be done to determine the applicability and effectiveness of the oil under ex vitro conditions. 


\section{Acknowledgment}

The authors wish to thank to CNPq (Conselho Nacional de Desenvolvimento Científico e Tecnológico - National Council for Scientific and Technological Development) and FAPEAM (Foundation for Research Support of the State of Amazonas) for providing a scholarship to R. A. Lima e A.G.S. Braga. Financial support was also provided by Embrapa (Empresa Brasileira de Pesquisa Agropecuária - Brazilian Agricultural Research Corporation).

\section{Reference}

AGAREZ, F.V. Botânica: taxonomia, morfologia e reprodução dos angiospermae: Chaves para determinação das famílias. AGAREZ, F.V.; PEREIRA, C.; ATÍDIO, C. (Eds.). 2.ed. Rio de Janeiro: Âmbito Cultural. 1994. p.233-4.

ALMEIDA, D.M.R.F.; REGITANO-D'ARCE, A.B. Antioxidant activity of rosemary and oregano ethanol extracts in soybean oil under thermal oxidation. Science and Technology the Food, v.20, n.2, p.197-203, 2000.

BRAGA, F.C. et al. Screening Brazilian plant species for in vitro inhibition of 5-lipoxygenase. Phytomedicine, v.6, n.6, p.447-52, 1999.

CASTRO, P.R.C.; KLUGE, R.A.; PERES, L.E.P. Manual de fisiologia vegetal. São Paulo: Agronômica Ceres Ltda, 2005. 650p.

CAVALCANTI, L.S.; COÊLHO, R.S.B.; PEREZ, J.O. Utilização de dois métodos de inoculação na avaliação da resistência de cultivares e linhagens de feijoeiro a Fusarium oxysporum F. SP. phaseoli. Ciência Rural, v.32, n.1, p.1-5, 2002.

CHAO, S.C.; YOUNG, D.S. Screening for inhibitory activity of essential or selected bactera, fungi and viruses. Journal Essential Oil Research, v.12, n.2, p.630-49, 2000.

CRAVEIRO, A.A.; FERNANDES, A.G.; ANDRADE, C.H.S. Óleos essenciais de plantas do Nordeste. Fortaleza: Edições UFC, 1981. 10p.

DAFERERA, D.J.; ZIOGASB, B.N.; POLISSIOU, M.G. The effectiveness of plant essential oils on the growth of Botrytis cinerea, Fusarium sp. and Clavibacter michiganensis subsp. michiganensis. Crop Protection, v.22, n.1, p.39-44, 2003.

FAROOQ, A. et al. Detoxification of terpinolene by plant pathogenic fungus Botrytis cinerea. Journal of Biosciences, v.57, n.9, p.863-6, 2002.

FIORI, A.C.G. et al. Antifungal activity of leaf extracts and essential oils of some medicinal plants against Didymella bryoniae. Journal of Phytopathology, v.148, n.8, p.483-7, 2000.

GIORDANI, R. et al. Antifungal effect of various essential oils against Candida albicans. Potentiation of antifungal action of amphotericin B by essential oil from Thymus vulgaris. Phytotherapy Research, v.18, n.12, p.990-5, 2004.

JOY, B.; RAJAN, A.; ABRAHAM, E. Antimicrobial activity and chemical composition of essential oil from Hedychium coronarium. Phytotherapy Research, v.21, n.5, p.439-43, 2007

KRAUZE-BARANOWSKA, M. et al. Antifungal activity of the essential oils from some species of the genus Pinus. Journal of Biosciences, v.57, n.5, p.478-82, 2002.

LORENZI, H. Botânica sistemática: guia ilustrado para identificação das famílias de Fanerógamas nativas e exóticas no Brasil, baseado em APG II. 2.ed. São Paulo: Instituto Plantarum. 2008. 704p.

MARTINS M. et al., Caracterização anatômica e fitoquímica de folhas e rizomas de Hedychium coronarium J. König (Zingiberaceae). Revista Brasileira de Plantas Medicinais, v.12, n.2, p.179187, 2010.

MATSUDA, H. et al. Labdane-type diterpenes with inhibitory effects on increase in vascular permeability and nitric oxide production from Hedychium coronarium. Bioorganic \& Medicinal Chemistry, v.10, n.8, p.2527-34, 2002.

MOREIRA, S.L.; FACUNDO, V.A. Estudo fitoquímico e farmacológico dos constituintes fixos e voláteis de Hedychium coronarium J. König. (Zingiberaceae). In: CONGRESSO BRASILEIRO DE QUÍMICA, 45., 2005, Belém. Anais... Belém: SBQ, 2005.

MUKHOPADHYAY, A.K. et al. Larvicidal properties of cashew nut shell liquid (Anacardium occidentale L.) on immature stages of two mosquito species. Journal Vector Borne, v.47, n.12, p.257-60, 2010

OBONGOYA, B.O.; WAGAI, S.O.; ODHIAMBO, G. Fungitoxic properties of four crude plant extracts on Fusarium oxysporum Schl. F. sp Phaseoli. Ajfand, v.9, n.8, p.1652-66, 2009. 
OYAMA, K.O.N. Avaliação Comparativa da Citoxidade in vitro dos Solventes Utilizados no Retratamento Endodôntico. 2003. 51p. Dissertação (Mestrado - Área de concentração em Odontologia) - Departamento de Odontologia, Faculdade de Odontologia, São Paulo.

PEREIRA, D.D. et al. Efeito do óleo essencial de plantas medicinais sobre microorganismos contaminantes em cultivo in vitro. Revista Científica Rural, v.9, n.2, p.25-36, 2005.

PEREIRA, M.C. et al. Inibição do desenvolvimento fúngico através da utilização de óleos essenciais de condimentos. Ciência e Agrotecnologia, v.30, n.4, p.731-38, 2006.

SANTOS, S.B.; PEDRALLI, G.; MEYER, S.T. Aspectos da fenologia e ecologia de Hedychium coronarium (Zingiberaceae) na estação ecológica do Tripuí, Ouro Preto-MG. Planta daninha, v.23, n.2, p.175180, 2005.

SANTOS, E. et al. Oviposition activity of Aedes aegypti L. (Diptera: Culicidae) in response to different organic infusions. Neotropical Entomology, v.39, n.2, p.299-302, 2010.

SARTORATO, A.; RAVA, C.A. Principais doenças do feijoeiro comum e seu controle. Brasília: EMBRAPA-SPI. 1994. 300p.

SHIRAISHI, H.; ENAMI, Y; OKANO, S. Folsomia hidakana (Collembola) prevents damping-off disease in cabbage and Chinese cabbage by Rhizoctonia solani. Pedobiologia, v.47, n.1, p.33-38, 2003.

SILVA, A.C.P.R.; OLIVEIRA, M.N. Produção e dispersão de sementes em pimenta longa (Piper hispidinervum). Rio Branco: Embrapa Acre, 2000. 14p. (Boletim de Pesquisa).

SILVA, I.D. et al. Efeito do extrato de sucupira (Pterodon emarginatus Vog.) sobre o desenvolvimento de fungos e bactérias fitopatogênicos. Pesquisa Agropecuária Tropical, v.35, n.2, p.109-15, 2005.

SILVA, I.L. Utilização de óleos vegetais para controle do fungo Thanatephorus cucumeris da mela do feijoeiro comum. 2005. 43p. Monografia (Graduação em Biologia) - Departamento de Biologia, Universidade Federal de Rondônia, Porto Velho.

TAVEIRA, F.N. et al. Epimers of labdane diterpenes from the rhizomes of Hedychiym coronarium J.
Koenig. Revista Brasileira de Farmacognosia, v.15, n.1, p.55-9, 2005.

ZAMBOLIM L.; VALE, F.X.R.; COSTA H. Controle de doenças de plantas hortaliças. Viçosa: UFV, 2000. $444 \mathrm{p}$. 